\title{
FAKTOR -FAKTOR PENYEBAB TERJADINYA Ca MAMAE PADA WANITA USIA SUBUR DI RSUP Dr. M.DJAMIL PADANG
}

\author{
Fanny Ayudia, M.Biomed \\ Akademi Kebidanan Alifah Padang \\ Email: fannyayudia@yahoo.co.id
}

\begin{abstract}
ABSTRAK
Menurut World Health Organitation ( WHO ) pada tahun 2010 bahwa kanker merupakan penyebab kematian nomor 2. Di Amerika terdapat 178.000 orang mengidap kanker payudara, prevalensi kanker payudara seimbang dengan peningkatan usia. Di Indonesia kejadian kanker payudara pada tahun 2007 diseluruh rumah sakit mencapai ( 16,85 \% ).Di Sumatera Barat tepatnya di RSUP M.Djamil Padang terjadi peningkatan setiap tahunnya pada tahun 2012 sebanyak 50 orang wanita yang menderita Ca mamae, pada tahun 2013 sebanyak 56 orang dan pada tahun 2014 sebanyak 65 orang. Tujuan penelitian ini yaitu untuk mengetahui faktor resiko terjadinya kanker payudara ( Ca mamae ) pada wanita pasangan usia subur di RSUP Dr.M.Djamil Padang.

Jenis penelitian ini adalah Deskriptif dengan desain penelitian Retrospektif. penelitian dilakukan bulan November 2016 - Juli 2017. Pengumpulan data dilakukan dari tanggal 11 - 21 Juli 2017. Jenis data ialah data sekunder, Populasi dalam penelitian ini adalah wanita pasangan usia subur yang mengidap kanker payudara sebanyak 91 orang pada tahun 2016. pengambilan sampel dengan teknik Total Populasi. Data diambil menggunakan lembar ceklis, dianalisis secara univariat, dan diolah secara komputerisasi.

Hasil penelitian menunjukan bahwa dari 91 wanita pasangan usia subur yang menderita kanker payudara ( Ca Mamae ) dengan faktor umur >30 tahun sebanyak ( 91,2 \% ), dengan faktor riwayat keturunan sebanyak ( 48,8 \% ). Dan dengan faktor kontrasepsi hormonal sebanyak ( 37,4\%).

Sebagian besar wanita pasangan usia subur memiliki umur $>30$ tahun yang merupakan factor dominan terjadinya Ca Mamae, kurang dari separoh wanita pasangan usia subur yang memiliki riwayat keturunan dan sebagian kecil wanita pasangan usia subur yang memiliki riwayat kontrasepsi hormonal yang merupakan factor terjadinya $\mathrm{Ca}$ mamae. Diharapkan dengan hasil penelitian ini dapat mendorong masyarakat untuk melaksanakan skrining pencegahan terjadinya kanker payudara ( Ca Mamae ).
\end{abstract}

\section{Kata Kunci : Umur, riwayat keturunan, kontrasepsi hormonal}

\section{ABSTRACT}

According to the World Health Organitation (WHO) in 2010 that cancer is the number 2 cause of death. In America there are 178,000 people with breast cancer, the prevalence of breast cancer is balanced with increasing age. In Indonesia the incidence of breast cancer in 2007 throughout the hospital reached (16.85\%). In West Sumatra precisely in the M.Djamil Hospital, Padang, there was an increase every year in 2012 as many as 50 women who suffered from Ca mommy, in 2013 as many as 56 people and in 2014 there were 65 people. The purpose of this study was to determine the risk factors for breast cancer (Ca mamae) in women of childbearing age at Dr.M.Djamil Hospital, Padang.

This type of research is descriptive with a retrospective research design. The study was conducted in November 2016 - July 2017. Data collection was carried out from July 11-21, 2017. Data types were secondary data. The population in this study were 91 women in reproductive age who developed breast cancer in 2016. Sampling with technique Total population. Data were taken using checklist, analyzed univariately, and processed computerized.

The results showed that of 91 women of childbearing age who suffered from breast cancer (Ca Mamae) with a factor of $>30$ years of age $(91.2 \%)$, with a history of hereditary factors $(48.8 \%)$. And with hormonal contraception factors $(37.4 \%)$.

The majority of women of childbearing age have age $>30$ years who are the dominant factors of $\mathrm{Ca}$ Mamae, less than half of women of childbearing age who have a history of heredity and a small percentage of women of childbearing age who have a history of hormonal contraception that is a factor in Ca mommy. 
It is expected that the results of this study can encourage people to carry out screening to prevent the occurrence of breast cancer (Ca Mamae

Keywords: Age, hereditary history, hormonal contraception

\section{PENDAHULUAN}

Masalah Kanker merupakan salah satu penyakit yang banyak menimbulkan kesengsaraan dan kematian pada manusia. Saat ini kanker menempati peringkat kedua penyebab kematian setelah penyakit jantung (Ghofar, 2009). Data World Health Organization (WHO) yang diterbitkan pada 2010 menyebutkan bahwa kanker merupakan penyebab kematian nomor 2 (dua) setelah penyakit kardiovaskuler (Depkes, 2012). Pada tahun 2008 di Amerika terdapat 178.000 orang mengidap kanker payudara (Nurcahyo, 2010). Menurut WHO, kanker payudara merupakan kanker yang paling sering terjadi pada wanita, $10 \%$ dari semua wanita di dunia menderita kanker payudara dalam hidupnya. Prevalensi kanker payudara meningkat seimbang dengan kenaikan usia, sebanyak 400 kasus baru dari 100.000 kasus setiap tahun terjadi (Hidayat dkk, 2009).

Menurut data statistik informasi rumah sakit ( SIRS ) kementrian Kesehatan Republik Indonesia pada tahun 2007 , kanker payudara adalah kanker terbanyak yang diderita wanita indonesia dengan angka kejadian 26 per 100.000wanita , disusul dengan kanker servik dengan angka kejadian 16 pr 100.000 wanita, dan kanker payudara menepati urutan pertama jumlah pasien rawat inap diseluruh rumah sakit diIndonesia ( $16,85 \%)$, dissusul dengan kanker servik $(11,78 \%)$.

Di Sumatera Barat, kejadian kanker $(5,57 \%)$ lebih tinggi dari rata rata nasional $(5,03 \%)$, yaitu dengan urutan tertinggi keenam dari 33 provinsi di indonesia (riskesdes, 2007 ), berdasarkan keterangan dari Kepala Institusi Humas dan pengaduan masyarakat RSUP Dr.M.DJamil Padang , mengatakan bahwa jumlah pasien masuk ke RSUP Dr. M. Djamil pada rentang tahun 2013, kasus kanker payudara menduduki posisi terbanyak pasien yang dirawat di RSUP M.Djamil Padang . ( febrida 2013 ).

Berdasarkan penelitian sebelumnya oleh Bobby Oscar Sihotang pada tahun 2011 tentang," gambaran faktor terjadinya Ca mamae di RSUP Adam Malik medan “, kanker merupakan slaah satu peyakit yang ditakuti oleh masyarakat, salah satu contohnya ialah kanker payudara . kanker payudara itu sendiri dapat terjadi dengan atau tanpa ada resiko pda penderita . marupakan hal yang paling penting untuk dapat mengetahui jumlah kejadian kanker payudara berdasarkan fakto faktor resiko tersebut .

Penelitian Bobby di RSUP Adam Malik Medan , tentang kanker payudara dengan menggunakan metode penelitian cross-sectional yang bertujuan untuk mengetahui proporsi faktor resiko yang dijumpai pada sampel . sampe dipilih dengan acak sederhana data dipilih di rekam medik. Pengolahan data dibantu dengan bantuan penggunaan komputer dan diperoleh faktor resiko yang paling sering dijumpai adalah riwayat penggunaan alat kontrasepsi hormonal ditemukan pada 36 responden $(39,6 \%)$ dari 91 responden.

Gejala permulaan kanker payudara sering tidak disadarai atau dirasakan dengan jelas oleh penderita sehingga banyak penderita yang berobat dalam keadaan lanjut . hal ini lah yang menyebabkan tinggi nya angka kematian kanker tersebut . padahal , pada satdium dini kematian akibat kanker masih dapat dicegah . kanker pda dasarnya berkembang sangat kambat , namun efek atau gejala yang bisa dirasakan atau dilihat dari pengidapnya bru muncul setelah ia mengalami perkembangan cukup luas dan tidak bisa dihentikan secara sederhana . umur penderita termuda adalah 20-29 tahun, yang tertua 80-89 tahun, dan yang terbanyak berumur 40-49 tahun yakni 130 kasus . kita belum mempunyai data kematian setiap tahunnya yang disebabkan oleh kanker payuadara ( ilmu kandungan , 2005).

Kemajuan dalam bidang terapi dan diagnostik memberikan dampak dalam penemuan dini terhadap penyakit kanker terutama kanker payudara . namun yang paling penting dari semua kemajuan teknologi yang ada adalah bagaimana seorang wanita mampu menyadari adanya perubahan awal dari organ tubuhnya sehingga kanker payudara dapat diindetifikasi sejak dini sebelum memasuki stadium lanjut . ( nurcahyo, 2010)

Berdasarkan survey awal di RSUP Dr. M.Djamil Padang pada tanggal 8 november 2016 . terdapat 91 data pasien yang menderita kanker payudara . menurut keterangan yang ada 
kanker paydara setiap tahunya terjadi peningkatan yang sangat signifikan pada tahun 2012 terdapat 50 orang wanita yang menderita ca mamae, tahun 2013 terdapat sekitar 56 orang wanita penderita ca mamae dan pada tahun 2014 terdapat kurang lebih 65 orang wanita penderita ca maame . dengan berbagai faktor resiko yaitu usia, riwayat keturunan dan kontrasepsi hormonal . maka dari itu peneliti tertarik untuk meneliti tentang,' Gambaran Faktor- Faktor Penyebab Ca Mamae Pada Wanita Usia Subur di RSUP Dr. M.Djamil Padang .

\section{METODA PENELITIAN}

Jenis penelitian yang dilaksanakan adalah penelitian deskriptif dengan rancangan penelitianyan Retrospektif

Populasi dari penelitian ini adalah seluruh wanita usia subur yang berada di bangsal bedah di RSUP DR.M.djamil Padang yaitu sebanyak 91 orang .Cara pengambilan sampel dalam penelitian ini adalah Total sampling (seluruh populasi dijadikan sampel )

\section{HASIL}

Analisis Univariat untuk menggambarkan distribusi frekuensi masing-masing variabel Umur, Riwayat Keturunan, Kontrasepsi Hormon. Dari penelitian yang telah dilakukan dari tanggal 11 - 21 Juli 2017 di RSUP Dr.M.Djamil Padang.

Tabel 1 Distribusi Frekuensi terjadinya Ca Mamae menurut Faktor Umur di RSUP Dr.M.Djamlil Padang

\begin{tabular}{lcc}
\hline Umur & $\mathbf{F}$ & $\mathbf{\%}$ \\
\hline$>30$ & 83 & 91,2 \\
tahun & 8 & 8,8 \\
$\leq 30$ & & \\
tahun & & 100,0 \\
\hline Total & 91 & \\
\hline
\end{tabular}

Berdasarkan Tabel 1 diketahui dari 91 wanita pasangan usia subur yang menderita $\mathrm{Ca}$ Mamaemenurut faktor umur yang > 30 tahun sebanyak 83 orang $(91,2 \%)$.
Tabel 2 Distribusi Frekuensi terjadinya Ca Mamae menurut Faktor Riwayat Keturunan Di RSUP Dr.M.Djamil Padang

\begin{tabular}{lcc}
\hline $\begin{array}{l}\text { Riwayat } \\
\text { keturunan }\end{array}$ & F & \% \\
\hline $\begin{array}{l}\text { ada } \\
\text { riwayat } \\
\text { tidak ada } \\
\text { riwayat }\end{array}$ & 44 & 48,4 \\
\hline Total & 47 & 51,6 \\
\hline
\end{tabular}

Berdasarkan Tabel 2 diketahui dari 91 wanita pasangan usia subur yang menderita Ca Mamae menurut faktor riwayat keturunan sebanyak 44 orang $(48,4 \%)$.

Tabel 3 Distribusi Frekuensi terjadinya Ca Mamae menurut FaktorKontrasepsi Hormon di RSUP Dr.M.Djamil Padang

\begin{tabular}{lll}
\hline $\begin{array}{l}\text { Kontrasepsi } \\
\text { hormon }\end{array}$ & f & \% \\
\hline $\begin{array}{l}\text { Hormon } \\
\text { Tidak } \\
\text { hormon }\end{array}$ & 34 & 37,4 \\
\hline Total & 57 & 62,6 \\
\hline
\end{tabular}

Berdasarkan tabel 3 diketahui, dari 91 wanita pasangan usia subur yang menderita Ca Mamae menurut faktor kontrasepsi hormon sebanyak 34 orang $(37,4 \%)$.

\section{PEMBAHASAN}

\section{a. Umur}

Berdasarkan tabel 1 diketahui wanita pasangan usia subur yang menderita Ca Mamae menurut faktor umur $>30$ tahun yaitu sebanyak 83 orang $(91,2 \%)$, sedangkan umur yang $<30$ tahun sebanyak 8 orang $(8,8 \%)$.

Hasil penelitian ini hampir sama dengan penelitian yang dilakukan oleh Helsia Septarini pada tahun 2013 di RSUP Serang dimana 
didapatkan wanita yang menderita Ca Mamae menurut faktor umur sebanyak 28 orang $(54,9 \%)$.

Resiko utama kanker payudara (Ca Mamae) adalah umur. Diperkirakan periode antara terjadinya haid pertama dengan saat kehamilan pertama merupakan window of initiation perkembangan kanker payudara. Secara anatomi dan fungsional, payudara akan mengalam atrofi dengan bertambahnya umur. Kurang dari $25 \%$ kanker payudara terjadi pada masa sebelum menoupose sehingga diperkirakan awal terjadinya tumor terjadi jauh sebelum perubahan klinis.

Faktor usia mempunyai hubungan erat terhadap faktor terjadinya Ca Mamae, penyakit ini lebih sering terjadi pada perempuan berusia diatas 50 tahun dan jarang terjadi pada perempuan sebelum monopouse, hampir $80 \%$ pada diagnosis awal kasus penyebaran sel kanker payudara terjadi pada perempuan diatas usia 50 tahun atau lebih. (America Cancer Society, 2005).

Peneliti berasumsi bahwa, umur yang dikatakan berisiko yaitu > 30 tahun karena merupakan window of initation atau jendela perkembangan. Dimana metabolisme didalam tubuh manusia melemah dan retan terhadap pertumbuhan sel kanker, seperti yang dialami oleh wanita pasangan usia subur yang sel-sel tubuhnya rentan terhadap pertumbuhan kanker yang semakin lama semakin mengganas dikarenakan ada beberapa faktor pemicunya seperti pola hidup tidak sehat, melahirkan usia > 35 tahun dan lain - lain. Dapat disarankan kepada wanita pasangan usia subur melakukan pemeriksaan secara dini dengan teknik pemeriksaan payudara sendiri ( sadari ), untuk mendeteksi sedini mungkim timbulnya benjolan pada payudara. Pemeriksaan ini dapat dilakukan secara berkala atau satu bulan sekal.

\section{b. Riwayat Keturunan}

Berdasarkan Tabel 2 diketahui wanita pasangan usia subur yang menderita Ca Mamae menurut faktor Riwayat Keturunan sebanyak 44 orang $(48,3 \%)$, sedangkan yang tidak ada riwayat keturunan sebanyak 47 orang ( 51,6\% ).

Hasil penelitian ini hampir sama dengan penelitian yang dilakukan oleh Bobby Oscar tahun 2011 di RSUP Adam Malik Medan dimana didapatkan faktor terjadinya $\mathrm{Ca}$ mamae menurut faktor riwayat keturunan sebanyak 10 orang (11\%).

Riwayat keluarga merupakan komponen yang penting dalam riwayat penderita yang akan dilaksanakan skrining untuk kanker payudara. Terdapat peningkatan risiko keganasan pada wanita yang keluarganya menderita kanker payudara. Pada studi genetik ditemukan bahwa kanker payudara berhubungan dengan gen tertentu. Sejumlah gen rusak yang diwariskan yang dapat meningkatkan kanker payudara telah diidentifikasi.

Peneliti berasumsi bahwa, dimana suatu penyakit bisa diturunkan melalui keturunan dalam bentuk sel DNA yang berupa BRCA 1 , yaitu suatu gen kerentanan terhadap kanker payudara. Gen ini akan menjadi cikal bakal untuk tumbuhnya sel kanker terutama $\mathrm{Ca}$ mamae. Wanita yang memiliki riwayat keluarga kanker payudara dapat menjalani tes Breast cancer gene di laboratorium karena gen BRCA merupakan pemicu tumor.

\section{c. Kontrasepsi Hormonal}

Berdasarkan tabel 3 diketahui wanita pasangan usia subur yang menderita Ca Mamae menurut faktor kontrasepsi Hormonal yaitu sebanyak 34 orang $(37,3 \%)$, sedangkan yang tidak memakai kontrasepsi hormonal sebanyak 57 orang $(62,6 \%)$.

Hasil penelitian ini hampir sama dengan penelitian Bobby Oscar tahun 2011 di RSUP Adam Malik Medan, dimana didapatkan pengaruh kontrasepsi hormonal dengan kejadian kanker payudara sebanyak 36 orang ( 39,6\% ).

Estrogen sangat mempengaruhi pertumbuhan jaringan payudara. Wanita yang terpapar estrogen dalam waktu yang lama akan memiliki resiko terhadap kanker payudara. Penggunaan kontrasepsi hormonal dalam jangka panjang dapat meningkatkan resiko kanker payudara. Sel-sel yang sensitive terhadap rangsangan hormonal mungkin mengalami perubahan degenerasi jinak atau menjadi ganas, ( Study Harvard School of Public Health).

Peneliti berasumsi bahwa,apabila penggunaan kontrasepsi yang mengandung hormonal terutama hormon estrogen yang 
dikonsumsi berlebihanatau jangka panjang akan meningkatkan resiko kanker payudara, karena sel-sel sensitif terhadap rangsangan hormonal yang akan mengalami perubahan menjadi jinak atau ganas. Hal inilah yang akan mempercepat pertumbuhan sel kanker pada wanita pasangan usia subur. disarankan kepada wanita pasangan usia subur bahwa pemakaian kontrasepsi hormonal dalam jangka panjang dapat menjadi faktor pemicu terjadinya kanker payudara. Oleh sebab itu berkonsultasi kembali kepada petugas kesehatan tentang penggunaan kontrasepsi yang aman bagi kesehatan.

\section{KESIMPULAN}

Dari hasil penelitian yang telah dilakukan dapat ditarik kesimpulan sebagai berikut :

1. Sebagian besar $(91,2 \%)$ wanita pasangan usia subur yang menderita Ca mamae memiliki umur > 30 tahun di RSUP.Dr.M.Djamil Padang pada tahun 2017.

2. Kurang dari separoh (48,3\%)wanita pasangan usia subur yang menderita Ca mamae memiliki riwayat keturunan di RSUP.Dr.M.Djamil Padang pada tahun 2017.

3. Sebagian kecil (37,3\%)wanita pasangan usia subur yang menderita $\mathrm{Ca}$ mamae memilik riwayat kontrasepsi hormonal di RSUP.Dr.M.Djamil Padang pada tahun 2017.

\section{DAFTAR PUSTAKA}

Afiyanti, Y. Dan Rachmawati, N.I. 2014. Metodologi penelitian .Jakarta: Rajawali Pers.

Arikunto, S. 2013. Prosedur Penelitian Suatu Pendekatan Praktek. Edisi Jakarta: Rineka Cipta.

America Cancer Society, 2005. How Many People Have Breast Cancer. http://www.cancer.org.

Budiarto, Eko, 2002. Biostatistik untuk Kedokteran dan Kesehatan Masyarakat, dalam: Arlinda Sari Wahyuni. 2007, Statistika Kedokteran.

Dr. Afriyanti ,SKp.,MN dan Anggi Pratiwi,Skep.2016. seksualitas dan kesehatan reproduksi perempuan.Jakarta : Rajawali Pers.

Febrida , Melly.Kasus Kanker Payudara . terbanyak di RSUP . M. Djamil Padang .liputan6 ( online ) 2013.
Hidayat, dkk.2009. Signifikan dari Kolerasi Uji Petanda Tumor dengan Sidik Tulang pada Pasien Kanker Payudara . Jurnal Ilmu Kedokteran Nuklir, Bandung : FK Padjajaran.

Kementerian Kesehatan RI. 2015 . Buku Saku Deteksi Dini Kanker Rahim dan Kanker Payudara Indonesia, Jakarta : Kemenkes RI

Manuaba, Ida Bagus.2010.ilmu kebidanan dan keluarga berencana.jakarta:EGC

Mansjoer,Arif . 2000. Kapita Selekta Kedokteran jilid 2 . jakarta : Media Aesculapius.

Notoatmojo,Soekidjo, 2010. Metodologi Penelitian Kesehatan, jakarta : Rineka Cipta

Oscar Bobby S, 2011. Gambaran Faktor - Faktor Terjadinya Ca Mamae di RSUP Adam Maleik medan tahun 2011. Medan : skripsi

Prof.Dr.dR.Prawirohardjho Sarwono,DSOG.2005.Ilmu Kandungan.Jakarta: Yayasan Bina Pustaka .

Rekam medik RSUP.M.Djamil tahun 2017.padang

Septariani Helsia, 2013. Gambaran Faktor Penyebab terjadinya Ca mamae di RSUP Serang tahun 2013. Serang : Skirpsi

WHO. 2003. Cancer Report. http://www.who.ini/topic/cancer/en. Diakses pada tanggal 20 Januari 2017. 